\title{
AN ANALYSIS OF PALM OIL PRICE FLUCTUATION IN THE FOREIGN MARKET
}

\author{
Buyung \\ Faculty Member of Education and Teacher Training College (STKIP) Pelita Nusa Bangsa \\ Binjai
}

\begin{abstract}
This research is aimed at investigating the impact of price and non-price on the demand for palm oil, supply and stock of palm oil in a foreign market. The data employed in this research were time series data. The analysis used the model of demand, supply and stock of palm oil. Full simultaneity in a dynamic model with inventories was adopted from Nerlove (1956). This research has shown that the supply of palm oil in the foreign market had a positive influence on the price, the area and the supply in previous years while the response of the demand was negative. On the other hand, the income and the demand in the previous years had a positive influence. The palm oil stock was influenced by the quantity in the previous years and international price.
\end{abstract}

\section{Keywords}

Price; non-price; palm oil foreign market realities

\section{JEL Classification}

$\mathrm{F} 1 ; \mathrm{L} 10$

\section{Introduction}

The main goal of long-term development is the realization of a strong foundation for the nation to grow and thrive on its own power to a just and prosperous society. It emphasizes on development with the main goal of achieving a balance between agriculture and industry as well as fulfillment of community needs.

Development that maintains the linkage between agricultural and industrial sectors is one of the required development strategies, especially by developing countries that have great potential in agricultural sector. Kuznets (1964) argued that agricultural sector has the potential to provide four major links to economic growth and development. First, agricultural sector in addition to providing raw materials that non-agricultural sector requires, or product contribution. Second, agricultural sector will produce goods for domestic marketing, or market contribution. Third, in line with the increase in economic growth and development, agricultural sector can be considered as main source of capital for investment, i.e. a process of transfer of surplus capital from agricultural to non-agricultural sector or factor contribution. Fourth, agricultural sector can contribute to the balance of payments through the development of production of import substitution or foreign exchange. Plantation is one of the agricultural sub-sectors that play a role in employment, development of production of new remote areas, supporting sector economic activities through the provision of raw materials, giving contribution which means to increase the country's foreign exchange, provision of foodstuffs and being able to improve the welfare of farmers. In agricultural development, the plantation sub-sector is expected to be directed to the achievement of plantation three dharma including (Mubyarto, 1983): financing, foreign exchange, creating job opportunities, conservation of natural resources. One of the commodities of the plantation sector contributes to the increase of Indonesian non-oil and gas export 
is a commodity of palm oil. Plantation area, volume and value of oil palm oil exports in Indonesia are shown in (table 1). In this table represents that the area of oil palm plantation in period of 1984 to 2000 had a tendency to increase, while the volume of exports went through a slight fluctuation, that is the decline in export volume in 1985 amounted to $63.01 \%, 1988$ of $2.78 \%$ and in 1993 was reducing by $11.79 \%$ and in 1996 there was a decrease of $22.45 \%$.

The decline in export volume was likely due to the decline in global palm oil prices in 1985 from US\$744.00/ton to US\$533.00/ton in the previous year. Similarly, there was a decrease from US\$348.68/ton in 1989 to US\$282.91/ton in 1990 (Table 1.2). Meanwhile in 1995, there was a change of government policy in terms of palm oil exports, related to the effort in order to ensure the availability of domestic (CPO) cooking oil raw materials. Thus, since 1994 the Minister of Finance enacted the Decree no. 439/KMK.017/1994 to impose an export tax on CPO based on the price of domestic cooking oil, i.e when the price was beyond Rp.1,250 per kilogram, then the government will apply export tax on CPO. The percentage change in the exports value every year seems immeasurably fluctuating. In 1984, there was a decline in export value by $43.23 \%$, in 1985 there was an increase by $162.56 \%$, and in 1986 declined again by $33.075 \%$, although export volumes increased during the year.

Palm oil plays an important role in the Indonesian economy, especially for raw materials for domestic cooking oil production, which is one of the nine kinds of community basic needs. In the past year, palm oil is the main raw material of cooking oil production, replacing coconut oil that has been declining in its production, and it cannot be relied upon to meet the demand for domestic cooking oil, especially its contribution to the stability of material price which is one of vastly contributing components in triggering inflation.

Table 1: Area, Value and Volume of Indonesian Palm Oil Exports (US\$ Million)

\begin{tabular}{|l|l|l|l|l|l|}
\hline Year & $\begin{array}{l}\text { Area } \\
\text { (Thousand } \\
\text { ha) }\end{array}$ & $\begin{array}{l}\text { Export } \\
\text { value of } \\
\text { palm oil }\end{array}$ & $\begin{array}{l}\text { \% } \\
\text { Export Value } \\
\text { Modifier }\end{array}$ & $\begin{array}{l}\text { Export } \\
\text { Volume } \\
\text { (Thousand } \\
\text { Ton) }\end{array}$ & $\begin{array}{l}\text { CPO Price } \\
\text { (US\$ } \\
\text { thousand/ } \\
\text { ton }\end{array}$ \\
\hline 1984 & 414.6000 & 111,5 & - & 345,8 & 744.00 \\
\hline 1985 & 549.6000 & 63,3 & $-43,23$ & 127,9 & 533.00 \\
\hline 1986 & 593.8000 & 166,2 & 162,56 & 437,8 & 257.00 \\
\hline 1987 & 713.3000 & 112,9 & $-32,07$ & 566,9 & 350.46 \\
\hline 1988 & 964.5000 & 112,9 & 27,46 & 551,1 & 422.72 \\
\hline 1989 & 1072.900 & 143,6 & 95,47 & 741,8 & 348.68 \\
\hline 1990 & 77599.30 & 280,7 & 19,98 & 781,9 & 282.91 \\
\hline 1991 & 1163.900 & 224,6 & $-9,35$ & 815,4 & 324.51 \\
\hline 1992 & 1259.300 & 203,6 & 64,73 & 1167,9 & 395.31 \\
\hline 1993 & 1405.500 & 335,4 & 6,32 & 1030,2 & 378.90 \\
\hline 1994 & 1437.700 & 356,6 & 32,47 & 1372,0 & 541.81 \\
\hline 1995 & 1650.900 & 472,4 & 51,95 & 1631,2 & 649.19 \\
\hline 1996 & 1885.200 & 717,8 & 4,11 & 1265,0 & 541.96 \\
\hline 1997 & 2552.300 & 825,5 & 10,46 & 1681,9 & 542.57 \\
\hline 1998 & 2768.600 & 1446,1 & 75,18 & 2891,7 & 656.53 \\
\hline 1999 & 2785.600 & 1535,4 & 6,15 & 3042,3 & 664.56 \\
\hline 2000 & 3171.600 & 1676,9 & 9,22 & 3321,5 & 687.68 \\
\hline
\end{tabular}

Source: Indonesia Economic Indicators (BPS), Indonesia Financial Statistics

(BI) $1984-2000$ (processed) 
Increasing plantation area and oil palm production is inseparable from the better market of this commodity in foreign market. The price of primary agricultural commodity increased slightly in global market during the first half of 1993. The prominent price increases were seen in rubber, pepper and palm oil. This price increase was mainly due to decreased production in some major income countries (BPS, 1993). The increased prices in export commodity can also be triggered by the declining of the Rupiah against the US dollar. However, these improvements cannot be optimally employed in a relatively long time. First, it was caused by hard crops commodity such as palm oil. The development of oil palm plantations in addition to those of state-owned enterprises, large foreign private plantations (PBSA) and large national private plantations (PBSN) were also developed by the community (small holder's estate) both individually and in partnership with large plantations, known as the core estate of the community (PIR). Development of Indonesian palm oil production is shown in table 2. In line with the increase of plantation area, the level of palm oil production is also increasing. The production level of the management pattern indicates varying speed of improvement. Production of government plantations had always surpassed the production of smallholder plantations, whereas the area of small holder plantations has increased above the government plantations in 1992. This indicates that productivity of small holders' estates is very low, possibly due to the lack of integration of the permanent process of small holders' estate products, with a large plantation-owned processing plant. As we know, in general, the small holders' estate develops in PIR pattern, in which the core estate shall accommodate production from small holders' estate to be processed into CPO. If the adjusted permanent timing of small holders' estates along with transport capacity and processing capacity of the plant is underestimated, it will result in excessively extended accumulation of FFB (Fresh Fruit Bunches) resulting in a decrease in oil "rendemen" (ratio of oil quantity produced from the extraction) and increase fatty acid levels. Besides, the low productivity of small holders' estate can also be caused by the length of the FFB distribution line to arrive at the processing plant, for example the small holder's estate sells their crops to the collecting traders that it may take up two days to process them into CPO. The FFB should be processed into CPO within a maximum of six hours after collecting. Private plantation production increased rapidly around 1994 and continued increasing to exceed government production in 1996. This was in line with the expanded area that began to increase beyond government plantations in 1989, thus the increase in production occurred about five or six years later. The average increase in oil palm production according to its management is 106.17 for small holder's estate and 12.63 percent for government plantations and 16.84 percent for private plantations.

Table 2: Development of Indonesian Palm Oil Production

\begin{tabular}{|c|c|c|c|c|c|c|c|c|}
\hline \multirow[b]{2}{*}{ Year } & \multirow[b]{2}{*}{ Small } & \multirow[b]{2}{*}{0} & \multirow[b]{2}{*}{ Government } & \multicolumn{2}{|c|}{ Production (Ton) } & \multirow[b]{2}{*}{$\frac{\circ}{0}$} & & \\
\hline & & & & & Private & & & \\
\hline & Holder & Change & Plantation & $\frac{0}{0}$ & Plantation & Change & Total & Change \\
\hline 1983 & 539 & & 96338 & & 67539 & & 164416 & \\
\hline 1984 & 826 & 53.25 & MI AlI & 84.22 & 69058 & 2,25 & 247361 & 50.45 \\
\hline 1985 & 8816 & 967.31 & 178675 & 0.68 & 70966 & 2.76 & 258457 & 4.49 \\
\hline 1986 & 11663 & 32.29 & 198865 & 11.3 & 73000 & 2.87 & 283528 & 9.7 \\
\hline 1987 & 29933 & 156.65 & 213050 & 6.66 & 76066 & 4.2 & 319049 & 12.53 \\
\hline 1988 & 31230 & 4.33 & 220538 & 3.51 & 90899 & 19.5 & 342667 & 7.40 \\
\hline 1989 & 36736 & 17.63 & 236745 & 7.35 & 119408 & 31.36 & 392889 & 14.66 \\
\hline 1990 & 75390 & 105.22 & 249431 & 5.36 & 178982 & 49.89 & 503803 & 28.23 \\
\hline
\end{tabular}




\begin{tabular}{|r|c|c|c|c|c|c|c|c|}
\hline 1991 & 85443 & 13.33 & 285096 & 14.3 & 180806 & 1.02 & 551345 & 9.44 \\
\hline 1992 & 99822 & 16.83 & 287896 & 0.98 & 171556 & -5.12 & 559274 & 1.44 \\
\hline 1993 & 104646 & 4.83 & 288762 & 0.30 & 208821 & 21.72 & 602229 & 7.68 \\
\hline 1994 & 162307 & 55.1 & 338741 & 17.31 & 295489 & 41.50 & 796537 & 32.26 \\
\hline 1995 & 195533 & 20.47 & 384393 & 13.48 & 362137 & 22.56 & 942063 & 18.27 \\
\hline 1996 & 233462 & 19.4 & 396850 & 3.24 & 454364 & 25.47 & 1084676 & 15.14 \\
\hline 1997 & 279604 & 19.76 & 423411 & 6.69 & 526318 & 15.84 & 1229333 & 13.34 \\
\hline
\end{tabular}

Source: $\quad$ Ministry of Forestry and Plantation, Directorate General of Plantation, 1998

Furthermore trading system is very important in agricultural development. Nevertheless, in the link of economy and flow of goods in Indonesia, trading system is the weakest part, or it has reasonably low efficiency. Similarly, in the case of oil palm commodity, small holders' estate sells FFB (Fresh Fruit Bunches) to collecting traders or large plantations at incredibly low prices. The owners of small estates have no mediums to improve their bargaining position. Conversely, large plantations also have less processing process to increase value-added commodities. It can be evident from the export commodity itself in crude palm oil (CPO). Senturi (1988) carried out an econometric analysis of the palm oil market in the United States. He used a model for the U.S. palm oil market formed with 3 behavioral equations and 4 identity equations. The behavioral equation includes function of global palm oil prices and function of quantity of the consumed palm oil and function of quantity of palm oil for final stock. He discovered that there was a positive correlation between global palm oil prices and function of quantity with the price of vegetable oil and animal fat. Consumption of palm oil in the United States is positively associated with the prices of vegetable oil, animal fats, fat processing and wage rates in food processing products and the lag of palm oil value is negatively related to the predicted global oil price. Palm oil stocks in the United States are positively related to the predicted global palm oil price, fat production in the same period, and lag from palm oil stockpiles, and negatively related to changes in global palm oil price and changes in fat production. Senturi concluded that palm oil competes with fats and vegetable oils in the U.S. market and palm oil can compete if the price is below the price of fats and vegetable oils. Palm oil is more versatile in end use not only for channeling but also for speculation.

Lubis (1998) developed a marketing model appropriate to the marketing of palm oil and took the case on production and marketing of Malaysian palm oil. He discovered that the performance of Malaysian palm oil marketing was influenced by marketing variables, especially international market variables such as global palm oil price and some oil substitution prices and policy instruments on the production. The price of Malaysian palm oil in the international market is determined by the price of global palm oil consumption. Although Malaysia is the world's major exporter of palm oil, it only serves as the recipient of the price.

Bond (1987) estimated export demand and supply with a regional approach for some export commodities based on data from 1963-1982. Assuming there was no substitution between the same export commodities in different regions. Hence estimates for demand and supply of foodstuffs, beverages and tobacco exports between Africa, Asia and Europe resulted that the price elasticity for demand of foodstuffs by the three regions was negative and significant at $\mathrm{a}=1 \%$ or a $-5 \%$. Price elasticity for demand of beverages and tobacco are negatively related, while income elasticity for beverages and tobacco are positively related.

\section{Research methods}

This study aims to investigate the main issues which are: 
(a) Response of palm oil supply represented by palm oil production, towards changes in palm oil prices, land area and supply in the previous year;

(b) Response of palm oil demand as represented by changes in palm oil prices, palm oil revenue and price in the previous year;

(c) Response of palm oil stocks to price changes, palm oil stocks in the previous year. Data that will be processed and analyzed is in the form of secondary data. Data has been linked to this research, including: Central Bureau of Statistics (BPS), Agriculture Agency and others and completed with literature study.

The model employed in this study is Full simultaneity in a dynamic model with inventories, derived from the Nerlove model, which are:

a. Supply function:

$\mathrm{St}^{*}=\mathrm{ao}+\mathrm{aiPt}+\mathrm{a} 2 \mathrm{At}+\mathrm{slt}$

b. Demand function:

$\mathrm{Dt} \mathrm{t}^{*}=\mathrm{bo}+\mathrm{b}, \mathrm{Pt}+\mathrm{b} 2 \mathrm{Yt}+\mathrm{S} 2 \mathrm{t}$

c. Stock Function:

$\mathrm{Kt} * \mathrm{Co}+\mathrm{C}, \mathrm{Pt}+£ 3 \mathrm{t}$

\section{Results and Discussion}

\section{Estimation Result of Palm Oil Demand Function}

Equation of palm oil demand function in the foreign market derived from the estimation result is as follows:

Ln Dt $=0,7125-0,22079 \mathrm{Ln} \mathrm{Pt}+0,67549 \mathrm{Ln} \mathrm{Yt}+0,0000016$

LnDt-i. The results of estimated palm oil demand function in the foreign market using the 2SLS method is presented in Table 3 below:

Table 3: Estimated Results of Demand Function Coefficient

\begin{tabular}{|c|c|c|c|c|}
\hline Variable & Coefficient & T. Ratio & P-Value & Significant \\
\hline $\mathrm{Pt}$ & $-0,22079$ & $-1,973$ & 0,069 & $\mathrm{~S}$ \\
\hline $\mathrm{Yt}$ & 0,67549 & 18,11 & 0,197 & $\mathrm{~S}$ \\
\hline $\mathrm{DM}$ & 0,000015932 & 1,526 & 0,001 & $\mathrm{~S}$ \\
\hline
\end{tabular}

Source: author's results

Remark: S - Significant, if T.Ratio > 1

From Table 3, it can be evident that coefficient value of independent variable-variance indicates the appropriate results to the demand theory. Variables of palm oil price have a negative correlation with palm oil demand with a coefficient value of -2.2979 , meaning that if the price of palm oil rises by $10 \%$ then the demand for palm oil will decrease by $2.2079 \%$. This indicates that palm oil price in foreign markets negatively affects the palm oil demand in foreign markets.

The income variable is positively related to the demand for palm oil. With coefficient value of income of 0.67549 means that if the consumer income increases by $10 \%$ then the demand for palm oil in foreign markets will increase by $6.7549 \%$. This indicates that if the income increases then the demand for palm oil will rise. Thereby it is clear that the income positively affects the demand for palm oil in foreign markets as indicated by the T-ratio of 18.11 .

The lag variable to the demand for palm oil is also positively related to the demand for palm oil with coefficient value of the previous year's demand of 0.000015932 means that if the previous year's demand increased by $10 \%$ then the 
demand for palm oil in foreign markets will rise by $0.00015932 \%$. This indicates that the previous year's demand positively affects to the demand of palm oil in foreign markets as indicated by the T-ratio of 1.526 . From the lag coefficient of one year demand (LQt) of 0,000015932 can count up the adjustment coefficient, which is by subtracting one to the coefficient. The obtained coefficient value is 0.999984068 or can be identified close to one. With the adjustment coefficient value approaching one there is precisely a little resistance in realizing the desired demand, thus the desired demand is almost the same as the ongoing demand. From the above explanation it can be concluded that the price of palm oil negatively affects the demand for palm oil in foreign markets. While the previous year's income and demand positively affects the demand for palm oil in foreign markets.

\section{Estimation of Function of Palm Oil Supply}

Equation of palm oil supply function in the foreign market derived from the estimation result is as follows: $\mathrm{Ln} \mathrm{St}=-1,4089+1,1917 \mathrm{Ln} \mathrm{Pt}+0,26505 \mathrm{Ln} \mathrm{At}+0,0000073 \mathrm{Ln}$ St-i The estimation of the palm oil supply function in foreign market also use 2SLS method as presented in Table 4 .

Table 4: Estimation of Coefficient Value of Supply Function

\begin{tabular}{ccccc}
\hline Variable & Coefficient & T. Ratio & P-Value & Significant \\
\hline LJ & 1,1917 & 3,073 & 0,008 & $\mathrm{~S}$ \\
LA & 0,26505 & 2,768 & 0,015 & $\mathrm{~S}$ \\
LS, & 0,000072943 & 1,537 & 0,147 & $\mathrm{~S}$ \\
\hline
\end{tabular}

Source: author's results

Remark: $\mathrm{S}=$ Significant, if $\mathrm{T}$. Ratio $>1$

From Table 4, it can be seen that variable of palm oil price in foreign markets are positively associated with the supply of palm oil in foreign markets with a coefficient of 1.1917 , meaning that if the price of palm oil rises $10 \%$, then the supply of palm oil palm oil will increase by $11.917 \%$. This indicates that the price of palm oil in foreign markets has significantly positive effect on the supply of palm oil in foreign markets indicated by the T-ratio of 3,073. While the variable of palm oil land area is positively associated with the supply of palm oil in foreign markets with a coefficient value of 0.26505 , it means that if the land area of oil palm increases by $10 \%$ then the supply of palm oil in foreign markets will increase by $2.6505 \%$. This indicates that the area of oil palm has a significant positive effect on the supply of palm oil in foreign markets which is indicated by the T-ratio of 2,768. Meanwhile, the variable of previous year's palm oil supply is positively related to the supply of palm oil in the foreign market with a coefficient value of 0.000072943 , meaning that if the previous year's palm oil supply increases by $10 \%$, then the supply of palm oil in foreign markets will rise by $0.00072943 \%$. This indicates that the previous year's palm oil supply positively affects the supply of palm oil in foreign markets as indicated by the T-ratio of 1.537 . From coefficient value of the 'lag' of one year supply (LSt) of 0, 000072943 it can be calculated the adjustment coefficient by subtracting one to the coefficient. The obtained 
coefficient value is 0.999927037 or can be identified close to one. By adjustment coefficient value exactly close to one, there is relatively little resistance in realizing the desired supply, thus the desired supply is almost the same as the ongoing supply. From the above explanation, it can be concluded that the price of palm oil, land area, and the previous year's supply had positively influenced to the supply of palm oil in foreign markets.

\section{Estimation of Palm Oil Stock Function}

Equation of palm oil stock function derived from the estimation results is as follows:

$$
\mathrm{Ln} \mathrm{Kt}=-1.0851+0.53292 \mathrm{Ln} \mathrm{Pt}+0.45574 \mathrm{Ln} \mathrm{K}_{\mathrm{M}}
$$

The estimated results of palm oil stock function using the 2SLS method is presented in Table 5 below :

\section{Table 5: Estimated Value of Stock Function Coefficients}

\begin{tabular}{lllll} 
Variable & Coefficient & T. Ratio & P-Value & \\
\hline & Significant & & & \\
LP & 0,53292 & 1,442 & 0,171 & $\mathrm{~S}$ \\
\hline LKi & 0,45574 & 1,983 & 0,067 & $\mathrm{~S}$ \\
\hline
\end{tabular}

Source: author's results

Remark: $\mathrm{S}=$ Significant, if $\mathrm{T}$. Ratio $>1$

From Table 5, the estimation of stock function parameters can be explained as follows: The variable of palm oil price was positively related to palm oil stock with coefficient value of 0,53292 , meaning that if the price rises $10 \%$, the palm oil stock will rise to $5.3292 \%$. This indicates that the price of palm oil has a significant positive effect on the palm oil stocks as represented by the T-ratio of 1.442 . While variables of the previous year's palm oil stocks were positively related to palm oil stocks with coefficient values of 0.45574 , meaning that if the previous year stock increased by $10 \%$, then the palm oil stock will rise by $4.5574 \%$. This indicates that the previous year's stocks positively affected the palm oil stocks as shown by the T-ratio of 1,983 . From the lag coefficient of one year demand (LQt) of 0,000015932 it can be counted up the adjustment coefficient by subtracting one to the coefficient. The obtained coefficient value was 0.999984068 or can be identified close to one. With the adjustment coefficient value approaching one precisely there was relatively little obstacle in realizing the desired demand, thus the desired demand is equal to the ongoing demand. From the above explanation, it can be concluded that the price of palm oil or palm oil stocks of the previous year had any real effect to the palm oil stock.

\section{Conclusions}

Based on the results of the discussion and analysis of demand and supply of palm oil in foreign markets as described and stated earlier, it can be drawn some conclusions and suggestions as follows: (a) The price of palm oil negatively affected the demand of palm oil in foreign markets. Whereas the income and demand of the previous year had a significant positive effect on the demand for palm oil in foreign markets; (b) The price of palm oil, land area and the previous year's supply positively affects the supply of palm oil in foreign markets; (c) The price of palm oil and palm oil stocks in the previous year have a significant effect on palm oil stocks; (d) The price of palm oil is significantly affected by the cumulative stock of palm oil. 


\section{References}

Adam, G. F. and J. R. Behrman, (1976), Economic Models of World Agricultural Commodity Market, Ballinger Publishing Company, Cambridge.

Bond, E. M., (1987), An Economic Study of Primary Commodity Export From Developing Country Regions to The World, International Monetary Fund Staff Papers, Volume 34 (2).

Chern, W. S., (1976), Acreage Response and Demand for Processing Tomatoes In California, American Journal Agriculture of Economic, Volume 58 (2).

Dirjen Perkebunan, Statistik Perkebunan Indonesia Tahun 1982 - 1988, Komoditi Pokok, Direktorat Jenderal Perkebunan, Jakarta.

Houthakker, H. S., and L. D. Taylor, (1970), Consumer Demand In United State Analysis and Projection, Harvard University Press, Second and Enlarged Edition, Cambridge, Massachusetts.

Kuznet, S, (1964), Economic Growth and the Contribution of Agriculture, in Eicher, C. K. and Witt, L.W. (eds). Agriculture in Economic Development, MC,Graw Hill. New York.

Labys, W.C, (1973), Dynamic Commodity Model For Forecasting and Policy Analysis, Nichol Publishing Company, New York.

Liebhafsky, H. H., (1970), Hakekat Teori Harga, Terjemahan Paul Sikotang, Bhratara, Jakarta.

Lubis, A Rahman, (1998), Production and Export Marketing Model (A Case Study for Malaysian Palm Oil) Kelala No 19/VII/1998 Universitas Gajah Mada.

Mubyarto, (1977), Pengantar Ekonomi Pertanian, LP3ES, Jakarta.

Nerlove, M, (1956), Estimates of Elasticities of Supply of Selected Agricultural Commodities, Journal of Farm Economics, Vol. 38,496-509.

Nerlove, M., (1958), Distributed Logs and Estimation of Long Run Supply and Demand Elasticities Theoritical Consideration, Journal of Farm Economics, Vol. 40, 301-311.

Riedel, J., (1988), The Demand For LDC Exports of Manufactures: Estimates From Hongkong, Economic Journal, Volume 98 (389).

Soekartawi, (1995), Prinsip Dasar Ekonomi Pertanian; Teori dan Aplikasi, Grafindo, Jakarta.

Soekartawi, (1995), Pembangunan Pertanian, Penerbit, PT. Raja Brafindo Persada, Jakarta.

Sumilat, Caleine. Aji, (1990), Tata Niaga Minyak Kelapa Sawit, No. 20. Departemen Perdagangan Jakarta.

Tomek, W. G. and K.L Robinson. (1972) Agricultural Product Prices, Cordele University --Press, Ithaca, New York. 